\title{
Moral Decadence Among Nigerian Youths As Future Leaders: A Socio-Cultural Regeneration
}

\author{
Adebisi Kolawole Shittu \\ General Studies Department, \\ The Polytechnic, Ibadan, Oyo State, Nigeria
}

\begin{abstract}
A day hardly ever pass without some media reports of ethno-religion conflicts, examination leakages, student unrest, secret cults, sexual abuse, certificate forgery, drug abuse and other cases of indiscipline across the country. Observations reveal that the youths are bad today, not only because of the negative societal influence but also because some homes have failed in their primary roles of inculcating socio-cultural values to the affected youths. This paper observes that moral regeneration of the Nigerian youths is not to be hinged solely and wholly on formal pedagogy. Traditional African people taught their young ones to be morally upright by devising effective and pragmatic ways of impacting certain ideals and virtues in them in order to mould them for leadership position of nation building in future. This discourse employs moral, social, cultural and theological springboards for the exposition through the use of secondary data. The paper recommended the reawakening of campaign on African traditional cultural values orientation and the encouragement of positive attitudes and values with the view of revamping the youths and the society from moral debility.
\end{abstract}

Keyword: Moral decadence, Youths, Moral regeneration, Socio-cultural values, Leadership

\section{INTRODUCTION}

Mohandas K. Ghandi, the father of Indian nation once says, "The things that will destroy the world are: politics without principle; pleasure without conscience; wealth without work; knowledge without character; business without morality; science without humanity and worship without sacrifice". The theory that man is a product of his society is not far from the truth as the process of individual character development derives a great influence from the values of the society in question (Albinus, 2012). The Nigerian youth is the future of the country just as the Nigerian child is the youth of tomorrow. In recent years, the mass media has been awash with reports on the spate of youth unemployment that has culminated in the alarming menace of street touts popularly referred to as 'Area Boys'. Prostitution, armed robbery, fraud, terrorism, kidnapping, ritual killing, street fighting and similar vices are now prevalent in the Nigerian society. A widely held perception which has been proved by research reports indicates that a high percentage of Nigerian youths who indulge in anti-social vices are products of lifestyles and practices that do not conform with appropriate and decent moral and cultural values that were transferred to the current generation of parents by the previous one. The extent to which parental irresponsibility is exhibited today will worry any Nigerian adult who is adequately informed about the threatening growth of a breed that has been properly positioned to promote vices capable of destroying Nigeria's tomorrow.

The phenomenon of moral decadence among the youths of Nigeria has reached an unbearable level. Recent research studies have shown that higher percentage of secondary schools and university students are engaging in various immoral activities such as examination malpractices, cultism, violence, cyber crimes, sexual immoralities, etc, and if something is not 
done to curb these vices, it may adversely degenerate the progress of this our country-Nigeria (Adebisi, 2013).Though moral decadence among youths has been majorly blamed on the parents (for lack of proper up-bringing of their kids) and the media (for exposing some critical scenes capable of polluting the innocent minds of the youths), our government on the other hand should not be left out as one of the prominent culprit. Nigeria leaders due to their corrupt practices have neglected the rule of law, show no respect to human rights, and are deeply involved in bribery and financial mismanagement. These corrupt practices have eaten deep into the nation's fabrics, and when a government cannot help her youth with employment, the youths in search of means of livelihood would involve themselves in various activities (legal/illegal) to make ends meet. However, since the system is corrupt, youths usually follow suit, as it is considered the faster route to make it in life. It is high time the government be more people oriented, create jobs and improve Nigerian economic status. They should try and practice true DEMOCRACY and not absolute AUTOCRACY.

The media has not been of great benefit in the fight against moral decadence. The information being broadcasted to the public, are most of the times not being censored. Youths that come across these information such as war films, pornographic scenes, drug addiction and trafficking scenes, etc, usually try to practice them directly or indirectly. Therefore, the media should scrutinized and deliver sound information that can be useful for the moral development of the youths. Also, some of the sophisticated technology products being produced also contribute their own quota. One could easily see what video games, blackberry pinging, face book, movie magic, super sports, etc, has done to the academic records of some youths, who abuse the purpose of their invention (Adebisi, 2013). The fight against moral decadence among youth is what everybody should join hands in combating. It should not be a question of who is to be blamed, rather, who is ready to help. Our government, corporate bodies, Medias and families should all join hands to help out. Nigeria youths too should learn how to help themselves by imbibing self discipline, having in mind that they are the leaders of the future.

In fact, one's heart is usually troubled as one considers the series of uncertainties of the youths that roam the street for lack of gainful employment and unstable academic sessions resulting from incessant closure of schools, colleges and universities for one problem or the other. It is the thrust of this paper to discuss the fact that some of our youths are bad today, not only because of the negative societal influence to which they are subjected; But also and much more, because some of our homes have failed in their primary roles in the inculcation of socialcultural values to the affected youths. The paper x-rays the place, position and prospects of youth mobilization for national development and at the same time proffer the use of traditional socio-cultural value regeneration as possible solution.

\section{CONCEPTUAL DISCOURSE ON YOUTHS AND MORAL DECADENCE}

The way in which a nation defines her youths is related to the objective conditions and realities that exist on the ground. That is why nations use different parameters and variables in defining their youths. In Nigeria, youth according to Mofoluwawo (2010) comprises all young persons of ages 17 to 30 who are citizens of the Federal Republic of Nigeria. This category represents the most active, volatile and yet the most vulnerable segment of the population socially, economically and emotionally. The youths can also be referred to as the younger generation in any society that are in the period of adolescence and one below the age of 40 years.

They are full of energy, exuberance and curiosity about life and the environment they find themselves. These attributes make them at that stage to be very vulnerable to social ills and vices, because, it is a period of uncertainty, doubts and exploration and even period of selfexploration and identification. Again Ajoma (2006) defines a youth as that person who is aged 
between 17s and 30 years. Alimba, Momodu, Abba \& Bello (2010) see a youth as somebody, who is within the age bracket of 15 and 34 years. These definitions was proposed by them because at the age 15 years, one is preparing to transit from secondary education to the society and at age 34 years, one is fully inducted into the society, since 30 years is the terminal point for being involved in National Youth Service Corp (NYSC ) programme. Therefore, the youthful age is a promising age in which a young man has the energy, will, courage and strength to be actively involved in adventures.

Moral can be defined as giving guidance on how to behave decently and honestly. It can also be seen as relating to issues of right and wrong and to how individuals should behave. It can be seen as something ethical, good, right, proper, honourable, just, principled etc. Decadence means the process of decline or decay in a society especially in its morals. It is also a state of immorality, corruption, debauchery, dissolution, self indulgence, profligacy, excess etc. From these definitions of moral and decadence, we can easily say what moral decadence is all about. Moral decadence is decline, decay and profligate in the moral values of individuals and society at large. It is the decay in the ethical values and norms that govern an individual and the society at large. A society where there is decline in moral values, what is wrong becomes right, what society should abhor becomes what they uphold (Afuye, 2013).

It is of no doubt that moral decadence has completely replaced core moral values in present times. This ravaging phenomenon is the cause of some of the major problems Nigeria is facing as a Nation. A society where the youths do not think of how tomorrow would be better than today or how to invent new things to automate processes involved in our daily activities rather focusing on how to enrich themselves by any means and controlling enormous wealth at a tender age (Afuye, 2013). Many youths of today are engulfed in numerous means of gathering wealth and enjoying the good things of life tagging it "hustling". When one ask an average youth what he does, he replies "I just dey hustle", one begin to wonder on what kind of job could it be that doesn't have a name. It is rampant and prevalent and as a result has reduced the present youths to mediocrity.

In the world today, shame and shamelessness are rewarded with encomiums and emphasized recognition, Unclothedness is now directly proportional to your fame and acceptance, skimpy dresses are now tickets to classy events, songs that have intimate talks in them sell faster than the meaningful ones, when your trousers is around your waist then you are seen as a "learner", big girls are now identified by level of exposure of their private parts. Even the world Religion and the institutions have failed in eradicating this dangerous way of life. What is the hope? Would the society continue to condone this act? Where will this lead us to? Is this how the great men of this world lived their youth lives?

Hence, Ajoma (2006) once remarked that youths are the trustees of any nation. In Indonesia, they are described as the "hope of the future" in Libya, "future partners" and in Nigeria, "leaders of tomorrow." From the above discussion it is crystal clear that in the business of building this country, the youths are the major stakeholder. Their composition when compare with other groups in the country is a pointer to this fact. The 2006 population profile of the country and the Restructured Age Distribution justify the position of this paper. The population censor reveals that the youths constitute the second largest group after the children's group. It can also be observed that the groups that make the youth (15-34 years) are more than half of the other groups combined (Mofoluwawo, Jarimi, \& Oyelade, 2012) . This is an indication that youth cannot be ignored in the scheme of things. They are the most active part of the population hence they should be given serious attention. If the youths are given the right types of values, skills, knowledge, motivation and the opportunity, the task of building the 
country rest on their shoulder. This paper therefore intends to state reason why much emphasis should be placed on the teaching of moral values in Nigerian society so as to produce youths with vivid sense of citizenship.

\section{AN OVERVIEW OF THE CONDITION OF NIGERIAN YOUTHS}

Youths have been placed on a scale of impoverishment which has affected their capacity to reason critically as young people in the business of developing the country as a result of increasing rates of poverty and unemployment in the country (Alimba, et al 2010). This was further worsening by the nature of the education that is being provided for them. There is also the problem of parental ineffectiveness in the education and moral upbringing of the youths as a result of unfavourable economic environment caused by poverty (Mofoluwawo 2010). Many youths because of family problem find it difficult to procure their basic needs like food, clothing, education etc. that can ensure their healthy living and development. Youth's inability to have these basic needs has pushed some of them to join the gang of armed robbers, hired assassins, political thuggery, drug pushers and the like to endanger themselves. Youths in their bid to pass examination or get employment by all means have turned to professional prostitutes and many of them have contacted HIV/AIDS or other sexually transmitted diseases like syphilis, gonorrhea. (Mofoluwawo 2010).

Many Nigerian youths who suppose to be leaders of tomorrow have died prematurely while many of them become useless instead of becoming useful to themselves and the nation at large. Nigeria youths have been demoralized, incapacitated and render unproductive. The ineffectiveness of the educational system and the bashing and deflating power of the society have impacted negatively on the youths to the extent that they are aimless (Alimba et al 2010). Youths have been involved in many things regardless of the nature of the task. That is, they are available to as many that are willing to give them "chop money" to sustain themselves even at the detriment to their lives. It is quite pathetic today that those within age bracket of 25-39 years have travelled oversea through the desert in search of greener pasture. The reason is because the government neither given them needed attention nor care for them to be effective and efficient in contributing actively to the building of the nation (Mofoluwawo et al, 2012).

The conditions of the youths in the country are so bad and frustrating to the extent that our leaders feel nothing is wrong since their children are not involved. The idea is that the bad state of the youths is associated with a crucial factor in the socio-political affairs of the country and that is the leadership factor. (Alimba et al 2010). Airahuobhor (2006) reiterated further that he regretted that Nigeria does not have leaders as yet; instead, it has rulers whom he described as thieves and scoundrels. A ruler, he says is a killer of consciousness and sows negative consciousness. He opined further that the politicians (i.e. our leaders) don't think beyond their pockets and have no vision. They do not understand the value of human being. This position is a pointer to the fact that the roles played by our leaders impoverish the state of the youths in this country. The average Nigerian does not have that instinctive sense of social cohesion which prevail in certain nation states of the world such as England, Germany, France just to mention a few (Okam, 2001). Nigerian youths are no longer upholding societal values like honesty, hard work, respect for elders and dignity of labour, cooperation, self reliance, decent dressing etc. The reason is because not much emphasis is placed on the teaching of moral education in Nigeria schools and homes.

Hence instead of producing thinking and objective human beings, the educational system produces many fearful and uncritical citizenry that are also selfish and indifferent to public affairs (Falade 2008). Through socio-cultural value regeneration, Nigerian youths who are leaders of tomorrow could be caught young and mould so that Nigeria will have a set of re- 
branding leaders in the future. Nigerian schools and homes should aim at developing in the citizens the spirit of effective citizenship and loyalty to the nation.

\section{CHALLENGES FACING YOUTH MOBILIZATION IN NIGERIAN SOCIETY}

One most veritable gauge to measure the progress of any nation is the degree of her commitment to the physical, spiritual, intellectual and technological development of the youths, obviously, youth constitutes the glory of a nation (Ogunbemi 2001). This ascertains is further strengthened by Remdex (1989) quoting Odumegwu Ojukwu that "No Nation can grow above its youths" The implication of this is that youths are the yardsticks for measuring the growth and development of any nation. However, it is heart-rending that the welfare package, ethical orientation and development of youth in Nigeria have fallen short of expectation. The impression created so far is that government is indifferent to the plight of the youths. In Nigeria, leadership problem has adversely affected human and natural resources resulting from incessant closure of schools, colleges, and mass unemployment. Constantly, youth are the first victims of starvation and peril (Awoniyi, 2003).

More so, it is important to stress the fact that socialization of the individual begins at home, and it continue largely under family domination during the individual's impressionable years. The Holy Bible says "Train up a child in the way he should go, and when he is old he will not depart from it". So, there is no denying the fact that the home provide the most decisive mould for individual's personality and social skills, the consequences which persist throughout life. Gbadamosi (1996) quoting Onyehalu (1988) affirms that members of the family make necessary inputs in the upbringing of the child. The basic life conditions change, and its institutions to adjust to them. For example, this has reflected in the changing roles of the family through introduction of western education, technological advancement and modern electronic gadgets. Starting from the age of one, a child begins to learn how to live alone compulsorily in a situation where both husband and wife are government workers. Also, the husband's work can move him away from the family sometimes to distant places from where he comes home occasionally and this makes it difficult for such father to discharge the expected roles. Besides, many educational, religious, recreational and other social functions hitherto performed by families have drifted rapidly into the hands of teachers, housemaids, day-care centres exclusively outside the homes. Onyehalu (1988) commenting on the changing role of the family on youth development stated that: "This new heritage and social order is bound to influence, hammer negatively, the behaviour and life style of our youths".

He noted further that there are seem to be more cases of social maladjustment and psychic disorders today than in the past when intimate child rearing prevailed. Leaving children to work out many personal problems alone or with inadequate damaging peer group guidance widens this social distance. Gbadamosi (1996) quoting Herbert (1969) sums up the message that:

The Kind of social distance usually resulting into boy's regressive ink-emptiness and crude manners. Girl's regressive silliness and irresponsibility because they strive to achieve emotional emancipation from parents secure initiation into moves of adult groups; and satisfactory hetero sexual adjustment.

The adverse effects of all these lackadaisical attitudes of government, parents, teachers in public and private schools on our youths cannot be over-emphasized. A visit to most of the penal institutions such as police station, court of law, remand homes and prisons has revealed that most of the criminal activities in the society are perpetrated by youths (Awoniyi, 2003). The youths engage in such wicked dealing as drug addiction, oil bunkering, hired assassin, forgery, arson, secret cult, ethno-religious fanaticism, "419" syndrome among others. All these 
activities are inimical and detrimental to the upliftment of the society. If the situation should continue unabated, then it connotes that the present and the future prospects of the society would be precarious because the youths who are supposed to be a dominant force for national development have otherwise turned to be social deviants (Alloy, 2000). Hence the need for this paper to awaken the government agents, families, school teachers from their slumber, so that they should be alive to their responsibilities most especially in educating the youths to ensure proper development in the society.

\section{MORAL DECADENCE AND SOCIO-CULTURAL REGENERATION}

Fasoro (2012) opines that the traditional Yoruba imparted moral values to the young ones through proverbs, storytelling, myths, religion chanting etc. The type of proverb to be uttered would depend on the context or situation at hand. For instance, despite the fact that the Yoruba did not condone a situation in which youth would be disrespectful to elders, they also expected the elders to put themselves in a position of honour. The following proverbs explain the point:

a. Bi omode ko ba ki agba, yoo simi ara re ni.

[If the youth does not greet the elder, he (the youth) will keep his peace. This shows that the youths are expected to greet the elders first]

However, there is also a proverb which says that the elders too ought to be alive to their social responsibilities because,

b. Ti okete ba dagba, omu omo re lo $\mathrm{n}$ mu.

(When the big rat grows old, it feeds on the milk of its young ones)

It is not the case that Yoruba proverbs were always coined to polarize the interests of the elders and those of the youths. There were also proverbs which encouraged mutual respect and cooperation. Such proverbs include:

c. Owo agba ko wo akengbe, owo omode ko to pepe.

(A child's arms cannot reach the high shelf; an adult's hand cannot enter the mouth of a gourd).

d. Otun we osi, osi we otun, oun ni owo fi n mo.

(The right arm washes the left; the left arm washes the right that is how both arms may become clean).

It was through the combination of myths, proverbs, songs, adages, and the rest, that traditional Yoruba society strove to inculcate, moral values to their children (Fasoro, 2012). This process of moral education may further be explicated as follows:

THE DON'T'S (myths and mythical beliefs), WHY? (Its believed or assumed implication); and the moral lesson derivable from the mythical belief:

1) The youth must not say the clothes of an elder smell. The youth would not grow to a ripe age to be regarded as an elder; to prevent waywardness on the part of the youth, to encourage respect for old age.

2) Refraining from merciless beating of domestic animals, to prevent giving birth to deformed children; Prevention of cruelty to animals; Encouragement of sympathy to all creatures. (In those days, cases of hired killings and armed robbery were not heard of).

3) Not walking and whistling at night. Such an act as this could disturb the witches that usually held their meetings at nights. The witches could be angered; hence they could harm that person. Social: Not constituting a nuisance to the neighborhood, because "Ijakumo kii rin 'de osan, eni a bii re kii rin 'ru" (A responsible person should not keep night outing).

4) Do not stand at the doorstep when it is raining. Sango, the god of thunder might be angered. Preventive: Avoid being hit by a thunderbolt.

5) Totemism: Avoid killing and eating of a particular animal. The first man of the tribe or clan was the one who changed to that animal; or he was, at the point death, assisted by 
that animal by showing him food and water. Respect for what as sacred and for old age and one's ancestral roots.

6) Do not stand while eating the person would never be satisfied. This is because the food that should go directly to his stomach would now be scattered all over his body especially his feet which might grow abnormally fat. To encourage good table manner, to eat in a relaxed atmosphere rather than fidgeting about while eating because "oba ni ounje" (Eating/food is supreme).

The people's belief in myths helped in promoting adherence to moral principles and rules. In a world believed to be inhabited and permeated through by spiritual powerful forces, forces that had absolute control on human conduct and destiny, it is not surprising if the world-view of such people were said to be heavily coloured by some metaphysical (or mythical) beliefs, moral convictions inclusive. The important thing to note here is that the world of the traditional Yoruba man was constituted in such a way that there were those divinities who were charged (by Olodumare - the supreme being) to watch over human conduct - to reward good deeds as well as to punish the bad ones. In his discussion of the Yoruba concept of human personality, Fasoro (2012) quoting Wande Abimbola (1975) notes that the Orisa (divinities) are generally believed to be helper of human beings against the forces of evil known collectively as ajogun. The Orisa however will project only those who lead moral and just lives. That is not all. The ancestors (and ancestresses) who are said to be next to the Orisa also play a prominent role in seeing to the day-to-day conduct of the living. The ancestors, Abimbola believes, could also be angry with a man who fails in his filial or moral responsibilities. Similarly, though the witches were believed to be very powerful, yet 'Olododo kii ku si oko ika' (the morally upright person is not usually destroyed, (does not usually die) by the evil machination of the wicked).

Again, the importance which was attached to strict observance of the rules and regulations guiding rituals, totems, sacrifices, cleansing, purifications, confessions of guilt and the subsequent atonements, and so on, was meant to inculcate moral values in the adherents of certain religions and festivities, as well as for the youths to respect what was believed to be sacred. Political, social and economic life was also imbued with some prohibitions, the observance of which was meant to make the people (morally) better citizens. One more avenue through which moral values were taught the youths among traditional Yoruba was their strong belief in the reality of after-life. The concept Orun (heaven) was meant to emphasize the need to work towards attaining eternal bliss but, by first of all being morally upright while one was still living on earth (aye).

One other observation worthy of note here is an element of relativism inherent in the moral system of the traditional Yoruba. The moral values that were taught through myths, songs, wise-sayings, and so on, were usually culture-bound, that is to say, many of these moral injunctions were restricted to particular cultures and religious practices. For instance, those food items and practices that were tabooed by adherents of a particular religion were not expected to be observed by people who did not practice that religion. However, there were also some beliefs and actions that cut across religious and cultural barriers. Among the traditional Yoruba, showing hospitality to strangers was not a practice that was expected to be restricted to a section of the society or a particular set of people.

\section{TOWARDS POSITIVE PREPARATION OF THE YOUTHS}

The step towards meaningful mobilization of the youths for national development has several dimensions. In part, the government should re-invest in our youths to enable them serve the purpose of our beloved society with the view to revalidating the positive side of our African 
traditional society and culture. First and foremost government should make a concrete policy on employment to accommodate millions of unemployed young graduates. It is when the problem of unemployment is frontally tacked that there can be cross-fertilization of noble ideas and values among the youths (Alloy, 2000). A Yoruba adage states that "an idle hand is an instrument for evil". Besides, government should build an enabling economic environment that can stimulate high productivity, increase growth, alleviate poverty and create gainful employment. The views of Ogunbemi (2001) attest to this charion call that:

Mobilization of youths deserves that the present leaders too should rediscover their primary focus and objectives towards national development. With correct motivation rather than mere empty words of promise that lacks substances, they can easily actualize their "gifted dreams" and this can make them an embodiment of all that is potentially good, beautiful and productive.

Apart from setting the endemic problem of unemployment, qualitative, quantitative and pragmatic education should be a cherished focus and legacy for the government to purse. A Yoruba adage state "Charity begins at home. Home is the oldest and most unique human institution and the cradle of discipline. Beside the provision of care, protection as well as the rudiments of social skills and etiquette made very early in life, the home should endeavour to perform counseling creditably well to ensure adequate and effective development of youths for a better society. According to Uka (1966): "Moral values are generalized guides by which individuals judge the reasonableness and appropriateness of their relationships with fellow men" moral training should start very early in life because once an attitude is formed, it is always difficult to part with. That is why youths be should made to demonstrated the virtues of obedience, honesty, truthfulness, love, politeness, humanity, respect, responsibility and accountability. Parents should intimate relationship with their youths. They should be no "social distance" between the parents and their youths.

Looking from the Christian, Islamic and traditional religious view points, there are relevant passage from the Holy Bible, Holy Quran and Ifa traditional corpus which establish the fact that youths need discipline, correction and good character. St. Paul teaches in Ephesians 6:4 that father, do not provoke your children to anger, but bring them up in the disciplined and instruction of the Lord" in a similar vein, in proverbs 19:18, this fact is corroborated, Discipline your son while there is hope, do not set your heart on his destruction.

In the Islamic standpoint it is apparent from the Holy Quran that:

0 my son! Establish regular prayer, enjoy what is just, and forbid what is wrong and bear with patient constancy what're betide thee; for this is firmness (of purpose) in (the conduct of) affairs.

Equally, significant to mention here is the African traditional religion. It is common saying in African milieu that "Eni Lori rere ti ko niwa, iwa lo maa bori re je" meaning that "however happy a person's destiny may be, if he has no character, it is character that will ruin his destiny" for the same reason, good character is copiously recommended in the odu corpus. One irete idi says:

Iwa pele I'okun aye

Ki ire peti lowo eni. O da fa fun orunmila

Ti o fi iwa pele gba okun aiye I'owo okan - le- ni irinwo irunmole.

"Gentle character it is which enables the rope of life to stay unbroken in one's hand. So declares the oracle to Orunmila who by means of gentle character was going to win the rope of life from the four hundred and one divinities". 
Good character is a sufficient amour against any untoward happening in life. All these allusions are point as to the fact that; God intended that the home vis-a-vis the society should inculcate in children cum youths the moral qualifies and principle, so as to develop habit and adjustments essential to good character. Religious institutions should therefore take up the challenges in remolding the youths' value discernment and ethical lives through prophetic role and social-ethical teaching in churches, traditional Religious forum, theological seminaries, Hospitals, Clinics, Orphanages and social welfare services in the society. Religious institution should seek to enforce moral value in youths by embodying in positive laws on issue like prostitution, prohibition against the use of mechanism of birth control, sale of alcoholic beverages, hard drugs, abortion etc.

Furthermore, home is the habitual place of abode, the scene of domestic life, with its emotional associations. In this connection the homes should provide psychological support in the times of distress, failure, misfortune, as well as proving achievement motivation for the youths. Considering the limited age and social exposure of the youths, they are emotionally weak and hardly can they absorb shocks. Frustration results whenever they experience the lightest disappointment such as failure in examination, being jilted, being unable to secure appointment, being sexually harassed among others. In this respect, the family or parents should not fail to give the necessary emotional assistance to the youths. Whenever they are in due need, otherwise they may become frustrated and some may take to deviant behaviours detrimental to the peace and stability of the home and society. Again, they should be made to know that success and failure are common phenomena in life. So whatever happens to man at any time should be taken in good faith, and see it as challenge in the life rather than being over joyous or despondent in case of success and failure respectively.

Another important area of fostering adequate development of the youth includes job orientation and financial assistance. They should be properly guided on the type and future of the job they are to embark upon based on their interest, ability and capacity. They should also be given financial backing whenever the need arises. The present state of economy in the country and the leadership palaver has made many parents renege on their responsibilities. Eventually this has led to various types of behavioural problems among the Nigerian youths. In order to remedy this ugly situation, we recommend strongly that the government should rediscover their primary focus and objectives towards the welfare, growth and development of the youths.

\section{CONCLUSION}

The discussions above reveal that the place and position of the youths in any society is cardinal. Youths are yardsticks measuring the growth of every nation such as the development and productivity of its industry, vibrancy of its economy, the integrity of its politics, the hope of its future, or the potential of its destiny, however, the government and the homes do not have the right focus on the youths. Based on this, there are great deals of deviant behaviours from the youths in the society. So, the paper argues that there should be general change of attitudes and motivations on the part of the government, at homes, religion bodies and people of thoughts in the society towards meaningful mobilization of the youths for national development in Nigeria. As it follows, in identifying and fostering the moral needs and proper care of the youth, youth should be taken as a community responsibility, which hopefully will tend to ensure a bright future prospects and progress in the society. Moreover, the tasks for youth's preparation for the positive widespread improvement of the society include to regularly organizing youth's seminars; parents' seminars; counseling service; regular parents information meeting to be organizing by schools and institutions on the updates of their wards. 
Obviously, if all the suggested solutions can properly implemented the position of the youths will definitely have positive side effects on the society.

\section{References}

Adebisi, H.S. (2013) Moral decadence" from http://www.blogspot.com.

Afuye , A.O. (2013) Moral Decadence in our Tertiary Institution vis-à-vis. The Study of Law in Nigeria retrieved fromwww.news@eaglereporters.com

Airahuobor A. (2006) Rulers, Yes, Leaders, Not yet. News Watch August 14. pp. 32-33

Ajuma, U.C. (2006) Developing Nigeria Youths via Business Education. JOWICE 10(2) pp. 65-71

Albninus, C. (2012) A Breed of Tomorrow's Troubles. www.modernghana .com

Alimba, C.N., Momodu, J.A, Abba, M.A \& Bello, M (2010) Education, Youth and National Development in Nigeria: Issues and Challenges. Africa Journal of Historical Sciences in Education 6(2) pp. 124-136

Alloy Ejiogu (2000) Morality and National Development: A Case for National Rebirth. Lagos: Superlative Services Ltd.

Aly, A.Y (1934) The Holy Quran. Berrut Dar-al Arabic Inc.

Awoniyi, S. (2003) Youths and National Development: A Socio-ethical Regeneration for our Present Age. Knowledge Review 6(1) pp. 95 - 100

Falade, D.A. (2006) Civil Education as a Tool for Nation Building in Nigeria. Journal of Social Studies XI(1) pp. 1528

Fasoro, J.O. (2012) Myth and Proverb as a Vehicle for Moral Education among Traditional Yoruba. International Journal of Arts and Commerce: 1(5) pp 225 - 262

Gbadamosi, G. (1985) The Role of the Family in Fostering Adequate Development of Youth. A Paper Presented at the Conference on Youths and Education, Organized by the Federal College of Education, Kantagora.

Herbert, B. (1969) Principles of Sociology. London: Barnes and Noble Pub., Inc

Mabogunje, A.L. (1981). The Development Process: A Spatial Perspective. Holmes and Merer Pub., Inc.

Mofoluwawo E.O, Jarimi, M. and Oyelade, T. (2012) The Instruction Mentality of Civil Education in Molding the Youths: A Case Study of College of Education Students in Oyo Town, Nigeria. International Journal of Humanities and Social Sciences 2(3) pp. 269-276

Mofoluwawo, E.0. (2006) Developing Nigerian Youth through Social Studies Education. The Achieves: MultiDisciplinary Journal of Humanities and Social Sciences. 11(2) p. 5

Ogungbemi, S. (2002). "Youths as Glory of a Nation” In Nigeria Tribune March 28, 2001 p. 12

Okam, C. C. (2001) The Challenges of the Curriculum Paradigm Implicit in life-long Education for National Building in Nigeria. Being a keynote address at the $8^{\text {th }}$ National Conference of the National Association of Curriculum.

Onyehalu, A. (1988). Psychological Foundations of Education. Akwa: Meks- Unique (Nig) Publisher.

Remdex (1989). Roles of Nigerian Youth in the Survival and Stability of the Third Republic. In the National Builder, Ibadan: Hope Otusanya press

The Holy Bible (R.S.V)

Uka, U. (1960) Grow up in Nigeria Culture. Ibadan: Institute of Education. 